\title{
Scholars Press
}

\section{A tradition of comminitment to scholarship}

Brown Judaic Studies is an interdisciplinary monograph series which surveys Judaic history, literature, philosophy, theology, and religion. The series publishes 20 to 30 new titles a year with over 150 titles already in print. Brown Studies on Jews and Their Societies is a social science monograph series that examines the social life of contemporary Jews throughout the world. A comprehensive purchasing plan is available; write for details. Price in parentheses available to members of sponsoring societies and Scholars Press journals.

SIFRA: An Analytical Translation

Jacob Neusner

Volume One: Introduction, Vayyiqra Dibura Denedabah and Vayyiqra Dibura Dehobah

Cloth: $\$ 37.95(\$ 24.95)$ $1-55540-205-4$

Volume Two: Sav, Shemini, Tazria, Negaim, Mesoram, and Zabim

Cloth: \$41.95 (\$27.95)

Volume Three: Ahare Mot, Qedoshim, Emor, Behar and Behuqotai

Cloth: $\$ 49.95(\$ 33.95)$

$1-55540-207-0$

SIFRA IN PERSPECTIVE: The Documentary Comparison of the Midrashim of Ancient Judaism

Jacob Neusner

Cloth: \$39.95 (\$26.95)

$1-55540-232-1$

THE DOCTRINE OF THE DIVINE NAME: An Introduction to Classical Kabbalistic Theology

Stephen $G$. Wald

This study presents an intelligible and authoritative account of the main elements of Kabbalistic thought and theology to the non-expert and scholar alike. The centerpiece of the work is the text, with translation and commentary, of the thirteenth century work The Secrets of the Letters of the Divine Name.

Cloth: \$35.95 (\$23.95)

$1-55540-242-9$

\section{ETYMOLOGY IN EARLY JEWISH INTERPRETATION: The Hebrew}

Names in Philo

Lester Grabbe

This work investigates the etymological method of Philo and, more generally, the use of this exegetical method in early Jewish literature.

Cloth: $\$ 49.95(\$ 34.95)$

\section{FESTSCHRIFT FOR MARVIN FOX}

Jacob Neusner, Ernest Frerichs, Nahum Sarna, and Leon Jick, editors

Forthcoming, Fall 1989.

Fifty scholars and friends of the master of Judaic studies in our time pay tribute to Prof. Marvin Fox on the eve of his retirement. 


\section{Books of BASIC Importance}

\section{DEATH AND BIRTH OF JUDAISM}

The Impact of Christianity, Secularism, and the Holocaust on Jewish Faith

JACOB NEUSNER

"An originai and challenging conceptual framework for thinking about the response of Judaism to historical crisis from Constantine's age to our own."-Robert Alter, UC Berkeley

"Jacob Neusner's mind is one of Judaism's greatest assets today."-William Safire, New York Times

$\$ 21.95$

\section{THE \\ ENCHANTMENTS OF JUDAISM \\ Rites of Transformation \\ from Birth through Death \\ JACOB NEUSNER}

"A literate and lucid introduction to some of the most important moments in the Jewish sacred liturgical calendar.... His profound learning... instructs the reader how moments in the here and now have been transformed into "paradigms of eternity'." - Rabbi Wolfe Kelman, The Rabbinical Assembly

$\$ 15.95$

\section{BORN GUILTY \\ Children of Nazi Families \\ PETER SICHROVSKY}

"An extraordinary book. It reveals a face of fascism that $I$ have never seen before, and in some ways cuts closer to the core of the Nazi system than anything else on the subject. A very subtle and important piece of work." - Howard Fast \$17.95

\section{THE NAZI DOCTORS Medical Killing and the Psychology of Genocide \\ ROBERT JAY LIFTON}

1987 National Jewish Book Award, Holocaust "Must reading.... The book as a whole stands without competition in the English language." - Raul Hilberg, author of The Destruction of the European Jews

"No one will be able, in my view, to write perceptively about those times in the future without referring to this interpretation." - Neal Ascherson, New York Review of Books \$12.95, paperback

\section{STRANGERS IN THEIR OWN LAND \\ Young Jews in Germany and Austria Today \\ PETER SICHROVSKY}

"Sichrovsky has found anger, loneliness and confusion to be common themes among the tiny first generation of German and Austrian Jews born after 1945.... Their courage is extreme, as the author shows us, and is to be greatly respected."-Boston Globe

$\$ 14.95$

\section{Coming in November}

\section{THE OTHER JEWS}

The Sephardim Today

DANIEL J. ELAZAR

"The first comprehensive history of the Sephardim, their resurgence in Israel and their revival throughout the rest of the Jewish world.

$\$ 21.95$

At your bookstore or from the publisher. Call toll-free 1-800-638-3030. 
Jewish Thought and Scholarship from

WAYNE STATE UNIVERSITY PRESS

\section{Josephus, the Bible, and History}

Edited by Louis H. Feldman

and Gohei Hata

500 pages

ISBN 0-8143-1982-3

ISBN 0-8143-1983-1

cloth, $\$ 49.50$ paper, $\$ 17.95$

\section{Prayer and Community}

The Havurah

in American Judaism

By Riv-Ellen Prell

300 pages, illustrated

ISBN 0-8143-1934-3

ISBN 0-8143-1935-1

cloth, $\$ 27.50$

paper, $\$ 14.95$

\section{Witness through} the Imagination

Jewish-American Holocaust

Literature

By S. Lillian Kremer

248 pages

ISBN 0-8143-2116-X cloth, $\$ 29.95$

ISBN 0-8143-2117-8 paper, $\$ 14.95$

Too Young to Remember

By Julie Heifitz

192 pages

ISBN 0-8143-2026-0

ISBN 0-8143-2027-9

cloth, $\$ 29.95$

paper, $\$ 14.95$

\section{People and Polity}

By Daniel J. Elazar

720 pages, $7 \times 10$

ISBN 0-8143-1843-6

\section{Ghosts of the Holocaust}

An Anthology of Poetry by Children of Holocaust Victims

Edited by Stewart J. Florsheim 128 pages

ISBN $0-8143-2052-X$

$\$ 15.95$

\section{The Year}

after the Riots

American Responses to the

Palestine Crisis of 1929-30

By Naomi W. Cohen

204 pages

ISBN 0-8143-1914-9

\section{Frankfurt}

\section{on the Hudson}

The German

Jewish Community

of Washington Heights, 1933-83,

Its Structure and Culture

By Steven M. Lowenstein

400 pages, illustrated

ISBN 0-8143-1960-2

Distributed for the Leo Baeck Institute. 


\section{American Assimilation or Jewish Revival?}

By Steven M. Cohen

"A penetrating description of the condition of American Jews and the most balanced treatment we have of the debate over how the condition can be interpreted."

-Charles S. Liebman, Bar-Ilan University

Are American Jews rapidly assimilating?

Or are American Jews undergoing a

great revival? This book addresses

this critical debate.

Jewish Political and

Social Studies

$\$ 27.50$

\section{European Jewry, 1933-1945}

By Richard Breitman and Alan M. Kraut

Explains America's failures to resist Nazi murder of European Jews.

The bureaucrats who made refugee policy were motivated by institutional priorities, not moral or humanitarian concerns.

$\$ 27.50$

To order, write or call 